\title{
Ecological aspects of managing the stressed- deformed state of the mountain massif during the development of multiple coal layers
}

\author{
Volodymyr Buzylo ${ }^{1}$, Artem Pavlychenko ${ }^{2 *}$, Tamara Savelieva ${ }^{3}$, and Olena Borysovska ${ }^{2}$ \\ ${ }^{1}$ National Mining University, Department of Underground Mining, 19 Yavornytskoho Ave., \\ 49005 Dnipro, Ukraine \\ ${ }^{2}$ National Mining University, Department of Ecology and Environmental Protection Technologies, \\ 19 Yavornytskoho Ave., 49005 Dnipro, Ukraine \\ ${ }^{3}$ National Mining University, Department of Machinery Design Fundamentals, 19 Yavornytskoho \\ Ave., 49005 Dnipro, Ukraine
}

\begin{abstract}
The ecological consequences of long-term development of coal deposits for the components of the environment, buildings, communications and infrastructure facilities have been analysed. The stress-deformed state of the rock massif around the preparatory working in the development of multiple coal layers is determined. The parameters of the development of the contiguous layers in the conditions of the mines of the Lviv-Volyn Coal Basin are substantiated. The complex of nature protection measures allowing to reduce the negative consequences of disturbance of the earth's surface in the development of multiple coal layers is substantiated.
\end{abstract}

\section{Introduction}

Coal has an important value in the global economy among natural energy resources and occupies the third position in terms of use after the oil and natural gas. The coal industry is an important component of the industrial potential of Ukraine and ensures the functioning of the leading sectors of the economy. The efficiency and stability of its functioning determines the sustainable development of the state, its energy and environmental security $[1-3]$.

Exhaustion of balance reserves, unprofitability of most mines, complex mining and geological conditions and an unstable economic situation have led to a deterioration of the ecological condition of the mining regions. This led to the emergence of a complex of social, economic and environmental problems, the main of them are: subsidence of the earth's surface, deformation and destruction of buildings and infrastructure [4-6]; formation of waste heaps (dumps) of rock accumulated over many years of coal mining [7]; flooding of land and living quarters, deterioration of the quality of underground and surface water [811]; the formation of explosive methane-air mixtures, etc. As a result of this situation, most of the coal-mining regions have become zones of ecological and social disaster [12].

\footnotetext{
* Corresponding author: pavlichenko.a.v@nmu.one
} 
The main tasks of managing the environmental safety of coal mining processes are to study the nature of the transformation of environmental components at all stages of field development [12-14]. In addition, it is necessary to introduce effective environmental measures timely, which will improve the quality of drinking water supply in coal mining regions [11, 15-17], as well as receive additional energy resources [18, 19].

The existing system of management of the ecological condition of coal mines doesn't allow proper solving environmental safety issues, both in the process of constant operation and further liquidation of coal mines [20-23]. Therefore, there is a need to establish patterns that govern the process of rock movement under the influence of underground mining of coal seams under natural objects, buildings, and settlements.

In this connection, the search for an analytical solution to the problem of rock mechanics is becoming topical in order to obtain a qualitative picture and quantitative estimates of the stressed deformed state (SDS) of the entire rock strata in conjunction with the parameters of the coal seam extraction at any stage of development. In this case, it is recommended to take into account the properties of the work-in-progress massif, the nature of the roof collapse, the intensity of the earth's surface displacement process, the depth of development, and specific mining and geological conditions [24, 25].

\section{The research problem setting}

The analysis of the literature sources revealed that the degree of negative influence of the reference pressure in the development of coal seams increases with the depth of development. So at a depth of 100 to $200 \mathrm{~m}$, the noticeable influence of the reference pressure in the case of the imposition of the boundaries of clearing works was observed for interbeds of $15-25 \mathrm{~m}$. At a depth of $300-340 \mathrm{~m}$, debris in cleaning and preparatory workings took place even at interbed thicknesses of $50-60 \mathrm{~m}$. This suggests that, in justifying the parameters for the development of the multiple contiguous layers, in each specific case, the SDS of the rock mass around the breakage face should be determined necessarily taking into account the overworking and (or) underworking, as well as taking into account the possible entry of the breakage face into the zone of pillars and layers selvages [24-27].

The speed of lowering the roof, hanging it behind the lining, the height of the inrush and the squeezing of coal are taken as the controlled parameters. It has been established that in the zone of increased rock pressure, the rate of lowering of the roof during the period of absence of the influence of production processes increases noticeably in comparison with the rate of lowering outside this zone $[28,29]$. In the proposed unloading zone, which is adjacent to the zone of influence, it is $1.5-2.0$ times smaller. In the zone of increased rock pressure, there was also an increase in the formation of the inrushes, with the height of the individual inrush reaching $0.8 \mathrm{~m}$, while outside the zone of influence it did not exceed $0.1-$ $0.2 \mathrm{~m}$. The actual angle of influence of the pillar $\left(\approx 84^{\circ}\right)$ is obtained. The largest hangings of the roof behind the lining (not counting the end sections of the lava), equal to one step of the lining movement, were $0.5-0.7$, and the largest values of the squeezing depth in the discharge zone were $0.4-0.5 \mathrm{~m}[26-29]$.

Obviously, there are not all the determining factors. For example, the formation may contain more than two closely spaced layers, an important role is played also by the physic and mechanical properties of coal and surrounding rocks that are not taken into account in the above-mentioned works, and so on. It is necessary to develop a methodology for calculating the values of subsidence of the earth's surface and recommendations for reducing the negative impact of surface underworking during the mining extraction of coal seams and rational management of coal reserves in safety pillars. But for this it is necessary to know the actual parameters of the demonstrations of rock pressure during the mining of 
coal seams using various development systems [28 - 31].

However, because of the consideration of the limited massif area in the vicinity of the breakage faces in the tasks of the mountain pressure with any method of solution, analytical or numerical, the determined stresses, deformations and deformation rates are not correlated with deformations of the earth's surface [24, 25, 29-31].

Most researchers associate the deformation of the earth's surface with angular parameters, consider, as a rule, the conditions of the completed process of displacement, and the main influencing factors are the depth of the coal layer and the dimensions of the breakage face. In this case, the data of mine surveying measurements are used, and therefore the obtained results do not possess sufficient generality [24, 25, 31, 32].

It should be noted that with underground coal mining irreversible changes occur in the rock mass that surrounds the working seam. These changes are a consequence of the collapse and subsidence of rocks over the breakage face, the redistribution of stresses around it. Changes in the mountain massif cause subsidence of the day surface over the mine workings. In addition to deformations from the influence of breakage heading, additional deformations and deformations of the mountain massif, the working seam and the earth's surface, are caused by the compression of the coal seam and host rocks under the influence of the reference pressure [32 - 35].

\section{Determination of the stressed-deformed state around the preparatory working in the mining of multiple layers}

The most important conditions for the safe operation of coal mines is to ensure the working condition of the entire network of mine workings from the surface to the breakage faces with minimal costs for their development and maintenance. The urgency of ensuring the operational stability of preparatory workings in the conditions of contiguous layers mining is constantly increasing due to the increase in the depth of mining operations [31-33]. At the same time, the nature of the distribution of rock pressure is significantly affected by overworking or underworking. Therefore, when choosing the method of protection and support of workings, especially in the case of weak enclosing rocks, it is necessary to proceed from the analysis of the SDS of the massif taking into account specific mining and technical situations as well as mining and geological conditions.

The layered heterogeneous environment in which the stress state of the roof and the soil of the contiguous layers undergoes significant changes under the influence of mining operations is typical for the mines of the Lviv-Volyn Basin. However, in the available industry documents regulating the location, protection and maintenance of mine workings, this change is accounted approximately by means of empirical coefficients established primarily for mining and geological conditions of other coal deposits. A similar approach is used in describing the structure of the rock massif.

To obtain quantitative estimates regarding the influence of interbed thickness and the depth of development, calculations were performed for a number of determining parameters (Fig. 1).

The analysis of the obtained data revealed that with a decrease in interbed thickness, the degree of stress growth in the reference pressure zone of the developing layer is increased. Thus, the maximum coefficient of stress concentration $\sigma_{y}$ in the roof of the layer in the cross-section $x=29 \mathrm{~m}$ in relation to the level of $\gamma H$ is $k_{y}=1.51$ at $h_{2}=6 \mathrm{~m}$ and $k_{y}=1.46$ at $h_{2}=20 \mathrm{~m}$. To a lesser extent the concentration of $k_{y}$ is affected by the development depth $H$ and at $H=300 \mathrm{~m}$ and at $H=600 \mathrm{~m}$ in the cross-section $x=29 \mathrm{~m}$ in the roof of the developing layer, $k_{y}$ has the same value.

In the arch of preparatory workings at a depth of $H=300 \mathrm{~m}$ at $h_{2}=6 \mathrm{~m}$, the coefficient of equivalent stress concentration, calculated by the criterion of P.P. Balandin, reaches a 
value of 2.1 and remains the same at a depth of $H=600 \mathrm{~m}$. The absolute value of the maximum equivalent tension at a depth $H=500 \mathrm{~m}$ becomes equal to the compressive strength of the rock, and at $H=600 \mathrm{~m}$ it is 1.2 times greater than it.

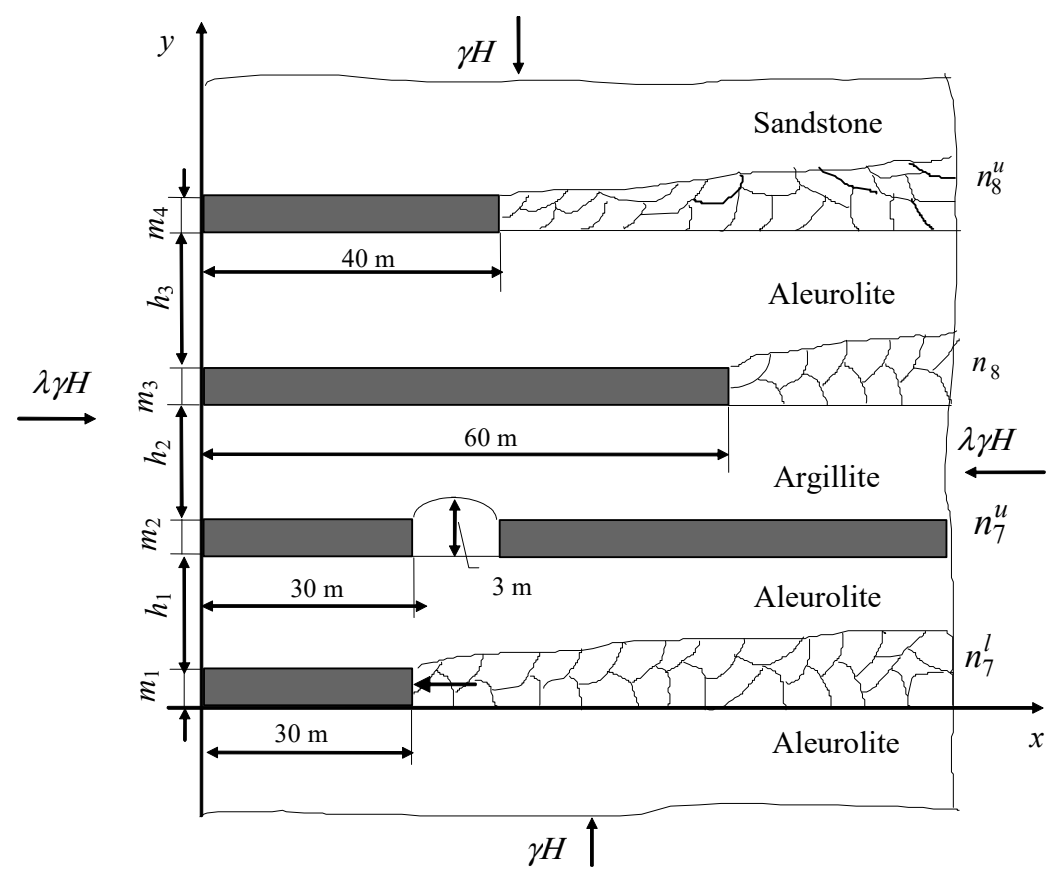

Fig. 1. The calculation scheme for determining the stress-deformed state of the massif around the working.

The growth of stresses in the massif surrounding the working, leads to an increase in the displacements on its contour. The performed studies showed that with increasing depth of development from 300 to $600 \mathrm{~m}$, the maximum vertical displacements $u_{y}$ in the arch grow by 1.79 times. Insufficient accounting of such SDS changes around preparatory workings that fall under the influence of clearing works on contiguous layers, when selecting lining, is one of the causes of deformation of preparatory workings.

\section{Justification of the parameters for the development of contiguous coal layers in the mines of the Lviv-Volyn basin}

Depending on the size of the mined-out space and the distance to the edge parts of the contiguous layers, in the roof and soil of the layer under development, zones of increased rock pressure of greater or lesser extent occur with different stress levels in them.

The most dangerous situation is the position of the line of the breakage face, in which overlay of reference pressure diagrams from the breakage face and the edge parts of the above- or lower-lying layer occurs in the roof and soil of the layer under development. The resulting total stresses, as a rule, exceed the admissible values. If, at the same time, a zone of extreme stress with considerable length is formed in the roof over the mined-out space, the mechanized lining is under great rock pressure [35-39]. The situation is aggravated by the fact that, a considerable additional load caused by the squeezing of coal is created by the tension of front moving breakage face $\sigma_{c}(V)$ under significant concentration of vertical normal stresses in the area of the reference pressure. As a result, an emergency situation may occur. 
Based on the possible limits of the variation of the variable values, the ratio $\gamma_{n} H /\left(\sigma_{c}\right)_{c}$ in the calculation assumed the values $[0.25 ; 0.27 ; 0.29 ; 0.31 ; 0.33 ; 0.35]$, and the ratio $E_{r} / E_{c}$ belonged to the area $[1.8 ; 2.8 ; 4.0]\left(E_{r}, E_{c}\right.$ - are the elastic moduli of the roof rock and coal, $\gamma_{r}$ - is the rock density of the roof, $\left(\sigma_{c}\right)_{c}$ - is the ultimate compressive strength of coal).

The geometric parameter of the investigated area $l / l_{n}$ assumed the values $[0.033 ; 0.166$; $0.33 ; 0.66]$. In this case, the length of the overworking zone was unchanged and amounted to $l_{n}=150 \mathrm{~m}$, and the size of the mined-out space behind the breakage face $l \in$ was $[5 ; 25$; $50 ; 100] \mathrm{m}$. The width of the edge part of the layer was $70 \mathrm{~m}$, the thickness of the interbed $h_{2}$ varied within $5-25 \mathrm{~m}$. In total, 152 calculation options were considered for overworking conditions.

The values of the maximum tension concentration coefficients $\left(K_{y}\right)_{\max }$ in zones of increased rock pressure in front of the breakage face, maximal approaches $(\Delta u)_{\max }$ of the soil and roof in the mined-out space and loads $P_{0}$, were obtained using the boundary elements method for different values of the distance $L$ between the breakage face and the edge parts of adjacent layers. On the basis of multiple correlation analysis of the obtained data, for the case of long face movement in the direction to the edge part of the adjacent layer under conditions of overworking, the ratios for the maximum values of the roof and soil approaches in long face in fractions of the thickness of the layer are established:

$$
\frac{\Delta u_{c}}{m}=0.107+0.097 \frac{l}{l_{n}}-0.065 \frac{E_{r}}{E_{c}}+0.530 \frac{\gamma_{r} H}{\left(\sigma_{c}\right)_{c}}
$$

as well as the maximum relative tensions in the roof of the developed layer in front of the breakage face:

$$
\left(K_{y}\right)_{\max }=\frac{\left(\sigma_{y y}\right)_{\max }}{\gamma_{n} H}=2.42+1.81 \frac{l}{l_{n}}-0.46 \frac{E_{c}}{E_{r}} .
$$

Similar dependencies with regard to the conditions of underworking are:

$$
\begin{aligned}
& \frac{\Delta u_{y}}{m}=-0.311+0.115 \frac{l}{l_{n}}+0.364 \frac{E_{c}}{E_{r}}+0.541 \frac{\gamma_{n} H}{\left(\sigma_{c}\right)_{y}} ; \\
& \left(K_{y}\right)_{\max }=\frac{\left(\sigma_{y y}\right)_{\max }}{\gamma_{n} H}=2.17+1.82 \frac{l}{l_{n}}+0.001 \frac{E_{c}}{E_{r}} .
\end{aligned}
$$

In addition, correlation dependences are established for the case of long face outflow from under the edge part, which in the conditions of overworking have the form:

$$
\begin{aligned}
& \frac{\Delta u_{y}}{m}=-0.314+0.350 \frac{l}{l_{n}}+0.310 \frac{E_{c}}{E_{r}}+0.446 \frac{\gamma_{n} H}{\left(\sigma_{c}\right)_{y}} ; \\
& \left(K_{y}\right)_{\max }=\frac{\left(\sigma_{y y}\right)_{\max }}{\gamma_{n} H}=2.38+2.468 \frac{l}{l_{n}}-0.196 \frac{E_{c}}{E_{r}} .
\end{aligned}
$$

For the case of long face outflow from under the edge part of the adjacent layer under the conditions of underworking, the following dependences were obtained:

$$
\frac{\Delta u_{y}}{m}=-0.280+0.301 \frac{l}{l_{n}}+0,285 \frac{E_{c}}{E_{r}}+0.433 \frac{\gamma_{n} H}{\left(\sigma_{c}\right)_{y}} ;
$$




$$
\left(K_{y}\right)_{\max }=\frac{\left(\sigma_{y y}\right)_{\max }}{\gamma_{n} H}=2.40+2.50 \frac{l}{l_{n}}-0,25 \frac{E_{c}}{E_{r}} .
$$

The correlation coefficients of dependences (1) and (2) are 0.88 and 0.82 , respectively. The correlation coefficients of dependences (3) and (4) are equal to 0.97. For dependencies (5), (6), (7) and (8), the correlation coefficients are $0.97,0.88,0.97$ and 0.89 , respectively.

Similar studies were carried out for the case when the extraction is performed simultaneously in the conditions of underworking and overworking. The results of calculating one of the variants $(L=65 \mathrm{~m})$ when the long face moves in the direction toward the edge part of the adjacent layer in the case of underworking in the form of diagrams of the normal tension $\sigma_{y}$ and vertical displacements $u_{y}$ are shown in Fig. 2 and 3 . Displacements in the long face in this case $\left(\Delta u_{y}\right)_{\max }$ do not exceed permissible for the mechanized support KM87.

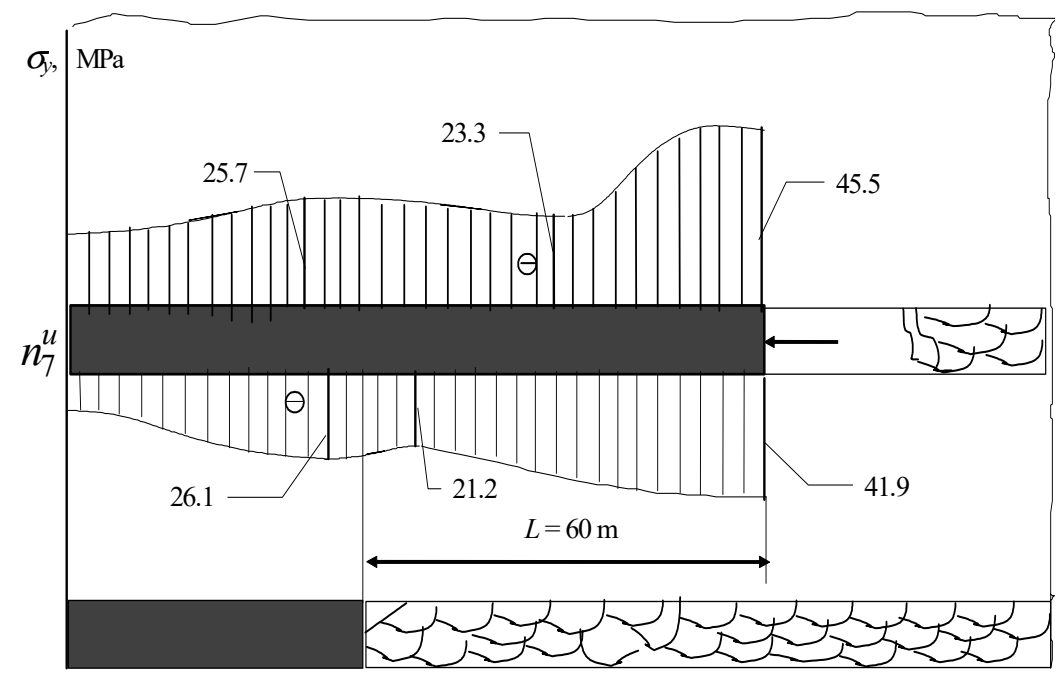

Fig. 2. Diagrams of normal stresses $\sigma_{y}$ in the roof and soil of the layer $n_{7}{ }^{u}$ (underworking, movement of long face to the edge part of the adjacent layer).

In this sense, for underworking conditions, the $L=65 \mathrm{~m}$ value is acceptable. A similar analysis of the SDS pattern in the case of overworking has shown that $L=60 \mathrm{~m}$ is permissible.

Let us find out how the coefficient of tension concentration and the speed of moving the long face $V$ affect the tension values $\sigma_{y}(V)$, appearing at the edge of the breakage face (in the cross-section $x=0$, Fig. 1) and creating an additional load on the mechanized support.

Suppose that the speed of the breakage face movement is $V=2 \mathrm{~m} /$ day $=0.083 \mathrm{~m} /$ hour. Then a strip of coal $S=1 \mathrm{~m}$ will be worked out for $t=6$ hours. The value of the tension concentration coefficient $\left(K_{y}\right)_{\max }$ at $L=65 \mathrm{~m}$ under conditions of underworking is 3.6 and, therefore, $K=\left(K_{y}\right)_{\max }-1=2.6$ (if $L<65 \mathrm{~m}$, then $\left(K_{y}\right)_{\max }>3.6$ and the strength condition is violated in the roof of the extractable layer in the zone of increased rock pressure in front of the breakage face). As a result of the calculations, we find that at a speed $V=4 \mathrm{~m} /$ day, $\sigma_{y}(V)=19.4 \mathrm{MPa}$. The corresponding calculations for the conditions, of overworking when $L=60 \mathrm{~m}$, give us: $\sigma_{y}(V)=7.56 \mathrm{MPa}$ at $V=2 \mathrm{~m} /$ day and $\sigma_{y}(V)=16.63 \mathrm{MPa}$ at $V=4 \mathrm{~m} /$ day. 


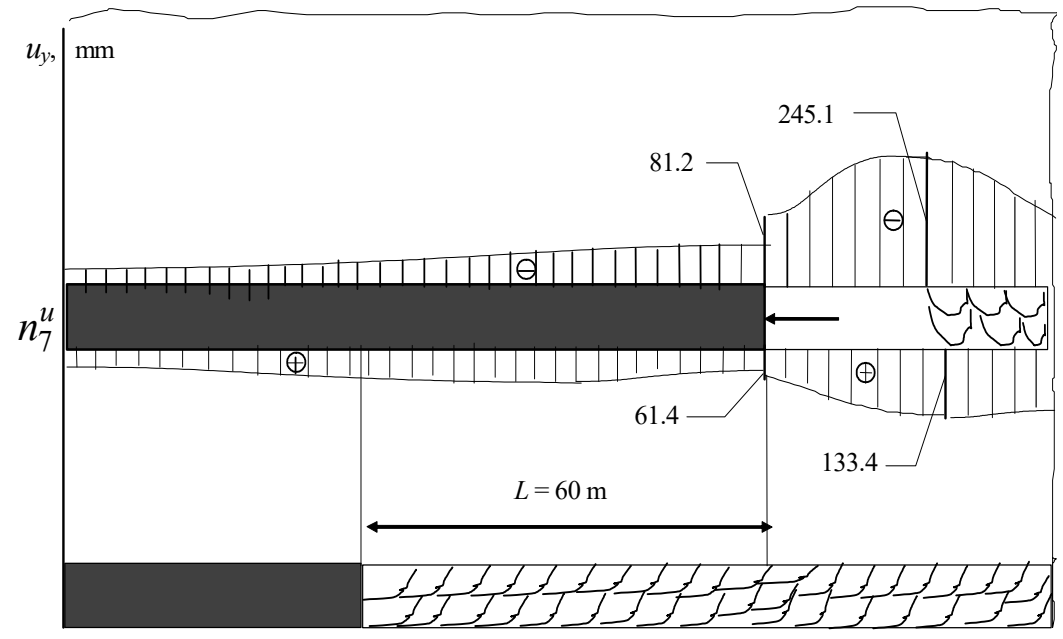

Fig. 3. Diagrams of vertical displacements $u_{y}$ in the roof and soil of the layer $n_{7}{ }^{u}$ (underworking, movement of long face to the edge part of the adjacent layer).

Consequently, in the cross section $x=0$ tensions are with increasing of rate $\sigma_{y}(V)$, and the faster the higher the tension concentration coefficient $\sigma_{y}$. However, this reduces the "removed" pressure, so the total load on the mechanized support decreases with increasing speed.

Of practical interest is the dependence of the value of the additional load $q(V)=0.03 \mathrm{P}(V)$ on the tension concentration factor $\left(K_{y}\right)_{\max }$. Such dependences for values of $V$, equal to $1.5 ; 2.0 ; 3.0$ and $4.2 \mathrm{~m} /$ day, are shown in Fig. 4.

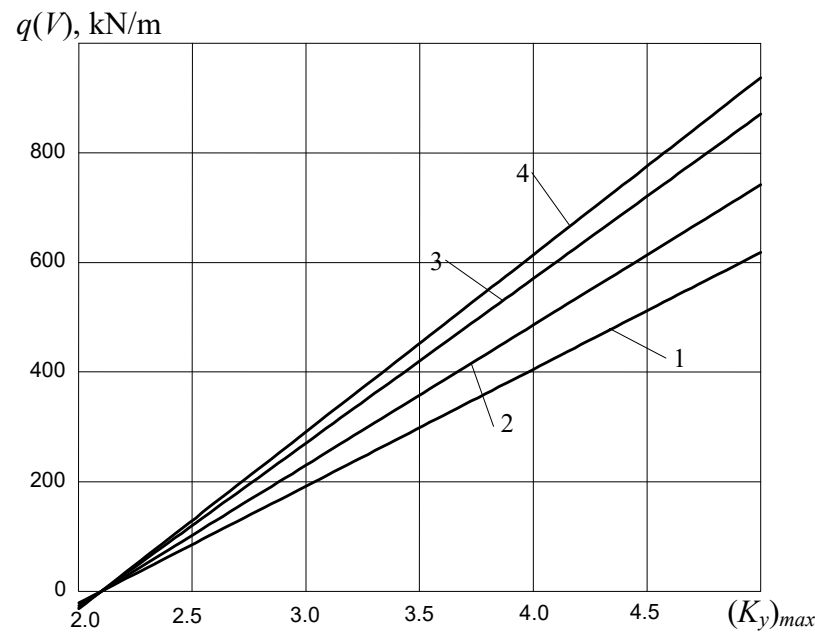

Fig. 4. The relationship between the additional load on the support and the coefficient of tension concentration: $1-V=4.2 \mathrm{~m} /$ day; $2-V=3.0 \mathrm{~m} /$ day; $3-V=2.0 \mathrm{~m} /$ day; $4-V=1.5 \mathrm{~m} /$ day.

Thus, given the values of $L, l / l_{n}$ and $E_{r} / \gamma_{n} H$ and using on one of the formulas (2), (4), (6), or (8), depending on the direction of the long face movement and the development conditions under consideration, one can find the corresponding value of maximum tension concentration factor in front of the breakage face $\left(K_{y}\right)_{\max }$, as well as the main load on the section of the mechanized support $P_{0}$ from the weight of the rocks in the zone of the 
ultimate stress state over the long face. Further, from the found value $\left(K_{y}\right)_{\max }$ from the graph in Fig. 4, we determine the additional load on the section of the mechanized support $q(V)=0.03 P(V)$ at a given speed of long face movement.

The disadvantage of this approach is the fact that the reference pressure zone is considered only in front of the breakage face, and increased rock pressure behind the breakage face affects the processes in the breakage face too. In addition, the angle $\delta$ within the interbed thickness, on which, first of all, the SDS of the massif area of interest depends (the vicinity of the breakage face), can significantly differ from the average value $\delta$ of the entire superincumbent rocks. Finally, the picture of the SDS of the soil and the roof of the layers being developed is also determined by the speed at which the breakage face is moved.

\section{Substantiation of ways to reduce the negative consequences of deformation and subsidence of the earth's surface in coal- mining regions}

When breakage faces are working, dynamic demonstrations of rock pressure are possible, expressed in the instantaneous destruction of the lower layers of the roof or a large part of the rock massif in the vicinity of the breakage face up to the cutting of the entire interbed, which can lead to a catastrophic increase in load on the support. In this case, there is a sharp decrease in the stability of the immediate roof, often there are cases of blockages of long faces, "strict" clamping of mechanized supports sections, and also squeezing of coal and soil swelling.

Rock displacements and deformations occur during underground mining of coal layers. These displacements cause significant changes in the field of gravitational forces with the formation of support zones, in which the tensions are several times higher than the tension of the untouched massif [30-33]. Changes in the rock massif, depending on the natural, mining, technical and production factors, lead to significant difficulties in cleaning works conduction. The harmful influence of the reference pressure is evident not only in the plane of the layer, but also in rocks at a considerable distance from it up to the surface [35-38]. Significant values of subsidence on the earth's surface contribute to the disruption of the ecological balance of the coal-mining regions.

Zones of compression of rocks arise as a result of the demonstration of the reference pressure, and are the main cause of subsidence of rocks and the earth's surface beyond the boundaries of clearing works. And, consequently, they determine the position in shift trough of the points with critical values of deformations, along which the initial angular parameters used to calculate the displacements and deformations of rocks and the earth's surface are determined.

Deformations of the surface, appearing under the influence of mining operations, along with the disturbance of the soil layer make it difficult to process agricultural land. It is established that the subsidence of the earth's surface to a depth of $3 \mathrm{~m}$ reduces soil fertility by $10 \%$, to $6 \mathrm{~m}-$ by $50 \%$. When the surface subsidence is more than $8 \mathrm{~m}$, the fertile soil layer is destroyed. Subsidence troughs are often filled with water, which causes flooding and waterlogging of land.

Protection of the surface from the negative effects of mining operations is possible in the following ways (or a combination thereof) [27, 31]:

- the abandonment of such coal pillars, when the disturbance of the earth's surface is prevented (thus a significant part of the coal reserves will be lost);

- implementation of a system of mining and technical measures to prevent or reduce subsidence of the earth's surface (laying the mined-out space with rock or a mixture of sand 
and clay, the use of chamber development systems, etc.);

- implementation of a system of measures on the surface to neutralize the negative consequences of mining operations (advanced and subsequent reclamation, the construction of artificial water reservoirs, etc.). With this method, in addition to large material and financial costs, the time factor also plays a role (there is much more time to reclaim the surface than to subjugate these territories).

One of the most realistic ways to significantly reduce the negative impact of mining operations and reduce the cost of restoring the lands and structures that have been worked on is the use of coal mining technology that provides for the full or partial laying of the mined out space. The goaf stowing of the mined-out space, with its massive application, makes it possible to change the nature of the displacement of the underworked mountain massif. The angles of displacement are changing; the process of displacement is stretching in time by a factor of $3-5$ compared with the total rock caving. The effectiveness of the goaf stowing is estimated by reducing the deformations of the underworked massif and the values of the surface lowering.

With the construction of filling massifs designed to protect underworked areas, the demand for high load-bearing capacity of the filling massif is in the foreground, which will minimize the displacement of the mined rocks and the harmful influence of underworking. However, the presence of high-quality filling material may not be sufficient if, for example, the goaf stowing of the mined-out space is made at a great distance from the breakage face of the long face, where significant subsidence of the roof rocks has already occurred. Therefore, the parameters of the technology used for development of the layer play not the least role in providing surface protection. It should be noted that the task of selecting the parameters of the filling massif and the influence of the technological parameters of layer development on the efficiency of goaf stowing, for the conditions of the main coal-mining basins, has not been completely solved.

Thus, the experience of applying a goaf stowing to the mined-out space indicates that prerequisites can be created for solving a whole complex of engineering and technical problems [39] in addition to reducing the number of rocks emitted from mines and improving due to this the ecological situation in coal-mining regions, the successful implementation of the protection of surface objects and the maintenance-free support of preparatory workings.

For example, due to full goaf stowing, methane flow into the breakage face from the mined-out space is sharply reduced and the probability of endogenous fires is completely eliminated, the intensity of the inrush formation process is reduced, and the state of the water resources of coal mining regions is improved [14, 40]. However, this experience was not continued due to increased labour intensity of work, reduced load on long face and the lack of incentives to improve the quality of extracted coal.

In view of the foregoing, in the projects for the preparation of breakage faces and in the passport for managing the roof and lining, it will be necessary to envisage the implementation of additional measures for managing the roof and of lining of the long face during the transition of zones of increased rock pressure that prevent or neutralize dangerous demonstrations of rock pressure. It is also necessary to continue developing methods to reduce subsidence of the earth's surface during the mining of coal layers, as well as to develop reserves under protected objects.

\section{Conclusions}

As a result of the studies, the following conclusions can be drawn:

1. On the basis of the method of boundary elements, an effective computational algorithm for determining the SDS of an inhomogeneous massif was developed with 
reference to the development of a multiple coal flat-lying layers.

2. Using the developed algorithm for the conditions of the mines of the Lviv-Volyn Coal Basin, the boundaries of zones of increased rock pressure in the roof and soil of the extracting layer are established, the values of the maximum tension concentration coefficients $\sigma_{y}$ relative to the $\gamma H$ level are determined, the load acting on the section of the mechanized support from the weight of rocks, located in the area of the ultimate tension state in the roof over the long face is found.

3. It is established that in the conditions of the mines of the state enterprise "Lvivvuhillia" during the work of breakage faces in the zones of influence of the edge parts of adjacent layers, the most dangerous from the point of view of the demonstration of rock pressure is the period of long face release from under the edge part of the underlying layer. Therefore, the rational power parameters of the mechanized support must be determined by the characteristics of the SDS of this particular area of the massif.

4. It is established that with the increase in the development depth from 300 to $600 \mathrm{~m}$, the maximum displacements $u_{y}$ in the arch of the preparatory working in the conditions of underworking increase 1.79 times.

5. One of the most realistic ways to significantly reduce the negative impact of mining operations and reduce the cost of restoring damaged lands and facilities is the use of coal mining technology, which provides for the full or partial goaf stowing of the mined-out space.

This work was conducted within the project "Development of technological bases of ecologically safe extraction of minerals in technogenic-loaded mining regions of Ukraine" (State registration No. 0117U001134).

\section{References}

1. Pivnyak, G.G., \& Shashenko, O.M. (2015). Innovations and safety for coal mines in Ukraine. Naukovyi Visnyk Natsionalnoho Hirnychoho Universytetu, (6), 118-121.

2. Petlovanyi, M., Lozynskyi, V., Saik, P., \& Sai, K. (2018). Modern experience of low-coal seams underground mining in Ukraine. International Journal Of Mining Science And Technology. https://doi.org/10.1016/j.ijmst.2018.05.014

3. Savchuk, V., Prykhodchenko, V., Buzylo, V., Prykhodchenko, D., \& Tykhonenko, V. (2013). Complex use of coal of Northern part of Donbass. Annual Scientific-Technical Collection Mining of Mineral Deposits 2013, 185-191. https://doi.org/10.1201/b16354-34

4. Belov, O., Shustov, O., Adamchuk, A. \& Hladun, O. (2018). Complex processing of brown coal in Ukraine: history, experience, practice, prospects. Solid State Phenomena, (277), 251-268. https://doi.org/10.4028/www.scientific.net/SSP.277.251

5. Mormul, T.M., \& Terekhov, Ye.V. (2017). Environmental and economic estimation of technological solutions in terms of land resource conservation in the process of open-cast mining. Naukovyi Visnyk Natsionalnoho Hirnychoho Universytetu, (3), 122-128.

6. Prokopenko, V. I., \& Litvinov, Yu. I. (2017). Environmental orientable imperative of developing the technology and excavation of horizontal fields. Naukovyy visnyk Natsionalnoho Hirnychoho Universytetu, (2), 51-57.

7. Gumenik, I.L., Lozhnikov, O.V., \& Panasenko, A.I. (2013). Deliberate dumping technology for mining reclamation effectiveness improvement. Naukovyi Visnyk Natsionalnoho Hirnychoho Universytetu, (5), 48-53.

8. Khomenko, O., Kononenko, M., Myronova, I., \& Sudakov, A. (2018). Increasing ecological safety during underground mining of iron-ore deposits. Naukovyi Visnyk Natsionalnoho Hirnychoho Universytetu, (2), 29-38. https://doi.org/10.29202/nvngu/2018-2/3

9. Cherniaiev, O.V. (2017). Systematization of the hard rock non-metallic mineral deposits for improvement of their mining technologies. Naukovyi Visnyk Natsionalnoho Hirnychoho Universytetu, (5), 11-17. 
10. Kolesnik, V.Ye., Fedotov, V.V., \& Buchavy, Yu.V. (2012). Generalized algorithm of diversification of waste rock dump handling technologies in coal mines. Naukovyi Visnyk Natsionalnoho Hirnychoho Universytetu, (4), 138-142.

11. Gomelya, M.D., Trus, I.M., \& Radovenchyk, I.V. (2014). Influence of stabilizing water treatment on weak acid cation exchange resin in acidic form on quality of mine water nanofiltration desalination. Naukovyi Visnyk Natsionalnoho Hirnychoho Universytetu, (5), 100-105.

12. Pavlichenko, A.V., \& Kroik, A.A. (2013). Geochemical assessment of the role of aeration zone rocks in pollution of ground waters by heavy metals. Naukovyi Visnyk Natsionalnoho Hirnychoho Universytetu, (5), 93-99.

13. Kolesnyk, V., Kulikova, D. \& Kovrov, S. (2013). In-stream settling tank for effective mine water clarification. Annual Scientific-Technical Collection - Mining of Mineral Deposits 2013, 285-289. https://doi.org/10.1201/b16354-53

14. Gorova, A., Pavlychenko, A., Kulyna, S., \& Shkremetko, O. (2012). Ecological problems of postindustrial mining areas. Geomechanical Processes During Underground Mining 2012, 35-40. https://doi.org/10.1201/b13157-7

15. Vambol, S., Vambol, V., Kondratenko, O., Suchikova, Y., \& Hurenko, O. (2017). Assessment of improvement of ecological safety of power plants by arranging the system of pollutant neutralization. Eastern-European Journal of Enterprise Technologies, 3(10(87), 63-73. https://doi.org/10.15587/1729-4061.2017.102314

16. Gorova, A., \& Klimkina, I. (2007). Methodology of Socio-Ecological Monitoring using Cytogenetic Methods. Multiple Stressors: A Challenge For The Future, 91-102. https://doi.org/10.1007/978-1-4020-6335-0 7

17. Malovanyy, A., Plaza, E., Trela, J., \& Malovanyy, M. (2014). Combination of ion exchange and partial nitritation/Anammox process for ammonium removal from mainstream municipal wastewater. Water Science \& Technology, 70(1), 144-151. https://doi.org/10.2166/wst.2014.208

18. Shmandiy, V., Bezdeneznych, L., Kharlamova, O. at al. (2017). Methods of salt content stabilization in circulating water supply systems. Chemistry \& Chemical Technology, 11(2), 242246. https://doi.org/10.23939/chcht11.02.242

19. Melnyk, L., Bessarab, O., Matko, S., \& Malovanyy, M. (2015). Adsorption of Heavy Metals Ions from Liquid Media by Palygorskite. Chemistry \& Chemical Technology, 9(4), 467-470. https://doi.org/10.23939/chcht09.04.467

20. Khomenko, O., Sudakov, A., Malanchuk, Z. \& Malanchuk, Ye. (2017). Principles of rock pressure energy usage during underground mining of deposits. Naukovyi Visnyk Natsionalnoho Hirnychoho Universytetu, (2), 35-43.

21. Malanchuk, Ye.Z., Lozynskyi, V.G., Dychkovskyi, R.O., Falshtynskyi, V.S., \& Saik, P.B. (2016). Experimental study of the influence of crossing the disjunctive geological fault on thermal regime of underground gasifier. Naukovyi Visnyk Natsionalnoho Hirnychoho Universytetu, (5), 21-29.

22. Bondarenko, V., Symanovych, G., \& Koval, O. (2012). The mechanism of over-coal thin-layered massif deformation of weak rocks in a longwall. Geomechanical Processes During Underground Mining 2012, 41-44. https://doi.org/10.1201/b13157-8

23. Khomenko, O. (2012). Implementation of energy method in study of zonal disintegration of rocks. Naukovyi Visnyk Natsionalnoho Hirnychoho Universytetu, (4), 44-54.

24. Bondarenko, V.I., Simanovich, G.A., Kovalevska, I.A., Fomichov, V.V., \& Serdiuk, V.P. (2007). Research of Rock Stresses and Deformations Around Mining Workings. Technical, Technological And Economical Aspects Of Thin-Seams Coal Mining, International Mining Forum 2007, 47-56.

25. Kovalevs'ka, I., Symanovych, G., \& Fomychov, V. (2013). Research of stress-strain state of cracked coal-containing massif near-the-working area using finite elements technique. Annual Scientific-Technical Collection - Mining of Mineral Deposits 2013, 159-163. https://doi.org/10.1201/b16354-28

26. Lozynskyi, V., Saik, P., Petlovanyi, M., Sai, K., \& Malanchuk, Y. (2018). Analytical Research of the Stress-Deformed State in the Rock Massif around Faulting. International Journal of 
Engineering Research In Africa, (35), 77-88. https://doi.org/10.4028/www.scientific.net/jera.35.77

27. Buzylo V., Yavorsk'yy, A., \& Yavorsk'yy. V. (2012). Analysis of stress-strain state of rock mass while mining chain pillars by chambers. Geomechanical Processes during Underground Mining 2012, 95-98. https://doi.org/10.1201/b13157-16

28. Khomenko, O., Kononenko, M., \& Bilegsaikhan, J. (2018). Classification of Theories about Rock $\begin{array}{llll}\text { Pressure. Solid State Phenomena, } & \text { (277), } & \text { 157-167. }\end{array}$ https://doi.org/10.4028/www.scientific.net/ssp.277.157

29. Shashenko, O.M., \& Kovrov, O.S. (2016). Comparative analysis of two failure criteria for rocks and massifs. Naukovyi Visnyk Natsionalnoho Hirnychoho Universytetu, (6), 54-59.

30. Soboliev, V., Bilan, N., \& Samovik, D. (2013). Magnetic stimulation of transformations in coal. Annual Scientific-Technical Collection - Mining of Mineral Deposits 2013, 221-225. https://doi.org/10.1201/b16354-41

31. Buzylo, V., Savelieva, T., \& Saveliev, V. (2012). Study of rock displacement with the help of equivalent materials using room-and-pillar mining method. Geomechanical Processes During Underground Mining 2012, 29-34. https://doi.org/10.1201/b13157-6

32. Kovalevska, I.A., Fomichov, V.V., \& Skitenko, A.I. (2012). Influence of stratification characteristics and inclination angle of rock massif on mine workings stability computational test results. Naukovyi Visnyk Natsionalnoho Hirnychoho Universytetu, (3), 31-36.

33. Babets, D.V., Sdvyzhkova, O.O., Larionov, M.H., \& Tereshchuk, R.M. (2017). Estimation of rock mass stability based on probability approach and rating systems. Naukovyi Visnyk Natsionalnoho Hirnychoho Universytetu. (2), 58-64.

34. Prusek, S. (2018). Perspektywy stosowania samodzielnej obudowy kotwowej w kopalniach JSW S.A. In XXVII Szkola eksploatacji podziemnej. Krakow.

35. Sdvizhkova, Ye.A., Babets, D.V., \& Smirnov, A.V. (2014). Support loading of assembly chamber in terms of Western Donbas plough longwall. Naukovyi Visnyk Natsionalnoho Hirnychoho Universytetu, (5), 26-32.

36. Fuławka, K., Mertuszka, P., \& Pytel, W. (2018). Monitoring of the stability of underground workings in Polish copper mines conditions. E3S Web Of Conferences, 29, 00008. https://doi.org/10.1051/e3sconf/20182900008

37. Pytel, W., \& Mertuszka, P. (2017). Blasting parameters alternate selection as a tool for elastic wave effect amplification at potentially instable locations within main roof strata. In 17th International Multidisciplinary Scientific Geoconference SGEM 2017. Science And Technologies In Geology, Exploration And Mining. https://doi.org/10.5593/sgem2017/13/s03.015

38. Vladyko, O., Kononenko, M., \& Khomenko, O. (2012). Imitating modeling stability of mine workings. Geomechanical Processes During Underground Mining 2012, 147-150. https://doi.org/10.1201/b13157-26

39. Kolosov, D., Bilous, O., Tantsura, H., \& Onyshchenko, S. (2018). Stress-strain state of a flat tractive-bearing element of a lifting and transporting machine at operational changes of its $\begin{array}{llll}\text { parameters. } \quad \text { Solid } & \text { State }\end{array}$ https://doi.org/10.4028/www.scientific.net/ssp.277.188

40. Adamenko, Y.O., Arkhypova, L.M., \& Mandryk, O.M. (2016). Territorial standard quality hidroekosystem protected areas, Hydrobiological Journal, 52(6), 51-59. 